\title{
Türkiye'de Sağlıklı Kentler ve Büyükşehir Belediyeleri Üzerine Karşılaştırmalı Bir Analiz
}

\author{
DOI: $10.26466 /$ opus.512721 \\ * \\ $\underline{\text { Aziz Belli* }}$ \\ * Dr. Öğr. Üyesi, Kahramanmaraş Sütçü İmam Üniversitesi, İ̈BF, Kamu Yönetimi \\ Bölümü,Kahramanmaraş/Türkiye \\ E-Mail: azizdarende@hotmail.com \\ ORCID: $0000-0002-1676-2769$
}

\section{Öz}

Sağllklı kent kavramına ilişkin çalışmalar Dünya Sağllk Örgütü'nün girişimleri sonucunda 1987 yılında başlamıştır. 1987 yılında başlayan Sağlıklı Kentler Projesi 5 yıllık fazlar halinde dünyanın birçok ülkesinde uygulanmıştır. Bu ülkelerden biri olan Türkiye'de sağllklı kentlere ilişkin uygulama ve işlemleri takip eden kuruluş Türkiye Sağllklı Kentler Birliği'dir. Türkiye Sağllklı Kentler Birliği'ne 30 Büyükşehir Belediyesinin 17'si üye olmuştur. 13 büyükşehrin üye olmaması hem kentsel alanlara hem de kırsal alanlara hizmet götüren büyükşehirler açısından önemli bir eksikliktir. Kentin sağlıkl olması sadece bireylerin fiziksel iyi oluşunu kapsamaz, psikolojik iyi oluş da dahil olmak üzere tüm çevrelerinin iyi olmasını sağlar. Kentleşmenin ortaya çıkardığı hızlı nüfus artışı ile ortaya çıkan büyükşehirlerde çevre ve sağlık sorunları insan hayatını olumsuz etkilemektedir. Bu kapsamda ortaya çıkan araştırma Büyükşehir belediyelerinin misyon ve vizyonlarında sağlıklı kent ifadelerine ne kadar yer verdiğinin ortaya koyulması amaçlanmıştır. Misyon ve vizyon kavramları büyükşehirlerin gelecek beklentileri ve temel hedeflerini ortaya koyması açısından değerlendirilmesi gereken önemli belgeler olduğundan incelemeye değer görülmüşü̈r. Çalışmanın amacını gerçekleştirmek üzere öncelikle kent, kentleşme, sağlıklı kent kavramları ortaya konulmuştur. Daha sonra büyükşehir belediyeleri ve Türkiye Sağlıklı Kentler Birliği kısaca incelenmiş ve büyükşehir belediyesi mevzuatı bu açıdan değerlendirilmiştir. Çalışmanın teorik çerçevesi oluşturulurken literatür taramasından hareketle yerli ve yabancı kaynaklardan elde edilen birincil ve ikincil verilere ulaşılmıştır. Çalışmanın alan araştırmasında vizyon ve misyonlarına ulaşılan 29 büyükşshir belediyesinde sağlıklı kent ifadelerinin hangi oranda yer aldığını ortaya koymak üzere içerik analizi yapılmıştır. Içerik analizi yapılırken Maxqda 12 programından faydalanılmıştır.

Anahtar Kelimeler: Kent, Kentleşme, Sağlıklı Kent, Misyon, Vizyon 


\title{
A Comparative Analysis of the Metropolitan Municipality and Healthy Cities in Turkey
}

\begin{abstract}
Studies on the concept of healthy city started in 1987 as a result of the initiative of the World Health Organization. The Healthy Cities Project, which started in 1987, has been implemented in many countries of the world in 5 year phases. In Turkey, which is one of these countries, the Turkish Healty Cities Association is the organization that follows the practices and procedures related to healthy cities. 17 of the 30 metropolitan municipalities became members of the Turkish Healthy Cities Association. The absence of 13 metropolitan municipalities is an important deficiency for the metropolitan cities that serve both urban and rural areas. The health of the city does not only involve the physical well-being of individuals, but also ensures that all their surroundings are well-suited, including psychological well-being, are good. In the metropolitan cities which are caused by rapid urban population growth, environmental and health problems negatively affect human life. Bu kapsamda ortaya çlkan araştırma Büyükşehir belediyelerinin misyon ve vizyonlarında sağlıklı kent ifadelerine ne kadar yer verdiğinin ortaya koyulması amaçlanmıştır. In this context, it is aimed to show how much space is given to healthy city expressions in the mission and vision of metropolitan municipalities. The concepts of Mission and vision are important because they are substantial documents that should be evaluated in terms of future expectations of metropolitan cities and their main objectives. In order to realize the purpose of the study, first of all, urban, urbanization and healthy urban concepts were introduced. Later, metropolitan municipalities and Turkey Healthy Cities Association examined briefly and municipal legislation is evaluated from this perspective. While the theoretical framework of the study was created, the primary and secondary data obtained from domestic and foreign sources were procured from the literature review. In the field study of the study, content analysis was performed in 29 metropolitan municipalities where the vision and missions were reached in order to determine the rate of healthy city expressions. In the field research, the visions and missions of 29 metropolitan municipalities were reached. Content analysis was performed to determine the rate at which healthy urban expressions take place. Content analysis was performed to determine the rate of healthy city expressions take place. During the content analysis, Maxqda 12 program was used.
\end{abstract}

Keywords: City, Urbanization, Healthy City, Mission, Vision 


\section{Giriş}

Kentler doğup, büyüyen ve zaman içerisinde yok olan organizmalar gibi canlı varlık olarak nitelenebilir. Her organizma için sağlıklı olmak yaşamın devamı ve organizmanın tüm yapılarının doğru ve sağlıklı açısından önemlidir. Kent sağlığı için temel göstergelerden birisi kentte yaşayan insanlardır. Kentte yaşayanların sağlık durumu iyi olduğu sürece kentin sağllğı da iyi olur (Belli ve Aydın, 2016, s.86). Diğer göstergeler kentte bulunan doğal ve yapay unsurların tamamıdır. Örneğin kent içerisindeki tarihi bir yapı kent sağlı̆ 1 açısından geleceğe devam ettirilmesi gereken bir yapıdır. Gelecek, geçmiş ve şimdiki zaman kavramları kent sağlığı açısından sürdürülebilir kalkınma kavramının önemli olduğunu ortaya koymaktadır.

Kentte yaşayanların sağlık durumunu etkileyen en önemli nedenlerden birisi kentleşmenin ortaya çıkardığı sorunlardır. Bu sorunlardaki artış ile birlikte çevre ve sağlık sorunları genellikle kentsel alanlarda ortaya çıkmaya başlamıştır. Kentleşme ile ortaya çıkan aşırı ve çarpık yapı birçok uluslararası örgütlenmenin ilgi alanına girdiği gibi Dünya Sağlık Örgütü'nün de ilgi alanına girmiştir. Kent açısından sağlıksız ortamların yaygın hale gelmesi ile DSÖ Sağlıklı Kentler Projesini geliştirmiştir. Hareket kısa sürede küresel bir dönüşüm yaşayarak birçok ülkede kabul görmüştür. Ülkemizde de Sağlıklı Kentler Birliği adı altında bir örgütlenme oluşturularak kentlerin daha yaşanabilir ve sağlıklı alanlar olması istenmiş ve projeden ülkemiz belediyelerinin de faydalanması istenmiştir. Belediyelerin projenin merkezinde olmasının sebebi, kentsel alanların belediye sınırları içerisinde olması ve sağlıklı kent yapısının oluşturulmasında belediyelerin etkin ve verimli hizmet sunan halka yakın birimler olmasındandır. Belediyeler içerisinden de büyüklük ve hizmet götürülen alan büyüklüğü açısından en geniş alana hizmet sunan birim büyükşehir belediyeleridir. Büyükşehir belediyeleri hizmet sunarken 5 yıllık sürede uygulanacak stratejik planları dikkate alırlar. Bu planlar hazırlanırken kurumun geleceğine yön veren kavramlardan olan misyon ve vizyon kavramlarının hizmet gereklerine uygun şekilde oluşturulması gerekmektedir. Kentler açısından sağlıklı olmak da önemli bir sorun olduğu için gelecek beklenti ve umutlar arasına sağlıklı kent olmak yatmalıdır. Bu kapsamda araştırmanın amacl; Büyükşehir 
belediyelerinin misyon ve vizyonlarında sağlıklı kent ifadelerine ne kadar yer verdiğini ortaya koymaktır.

Araştırmanın amacını gerçekleştirmek üzere öncelikle kent, kentleşme, sağlıklı kent, misyon ve vizyon kavramları açıklanmıştır. Daha sonra büyükşehir belediyelerinin sağlıklı kent açısından yasal anlamda ne durumda olduğu ortaya konulmaya çalışılmıştır. Araştırmanın bu kısmı hazırlanırken yerli ve yabancı kaynaklardan elde edilen birincil ve ikincil verilerden faydalanılmıştır. Büyükşehir belediyelerinin misyon ve vizyonları incelenirken tarama araştırması yolu ile büyükşehir belediyelerinin stratejik plan belgeleri incelenmiştir. Elde edilen misyon ve vizyon belgeleri üzerinden Maxqda programı ile içerik analizi yapılarak sağlıklı kent kavramının büyükşehir belediyeleri misyon ve vizyonlarında ne kadar yer bulduğu ortaya konulmuştur. Araştırma sonuç bölümü ile tamamlanmıştır.

\section{Kent ve Kentleşme Kavramı}

Kent kavramını farklı bakış açıları ile tanımlamak için öncelikle Türkiye'de bilinmeyen kavramlar açısından temel sözlük olarak belirlenen Türk Dil Kurumu sözlüğüne bakmak gerekmektedir. Kurumun sözlügünde kent, "nüfusunun çoğu ticaret, sanayi, hizmet veya yönetimle ilgili işlerle uğraşan, genellikle tarımsal etkinliklerin olmadığı yerleşim alanı" olarak tanımlanmaktadır. Tanımda sadece iktisadi bakış açısı yer almıştır. Kentleşme literatürü açısından önemli kaynaklardan biri olan Kent Bilim Terimleri Sözlügü̈nde kent, "sürekli toplumsal gelişme içinde bulunan toplumun, yerleşme, barınma, gidişgeliş, çalışma, dinlenme, eğlenme gibi gereksinimlerinin karşılandığı, pek az kimsenin tarımsal uğraşlarda bulunduğu, köylere bakarak nüfus yönünden daha yoğun olan ve küçük komşuluk birimlerinden oluşan yerleşim birimi" olarak tanımlanmaktadır. Ancak kent ile ilgili literatür incelendiğinde farklı kriterlere göre farklı tanımlamalar yapıldığ görülmektedir. Bu kriterler; iktisadi kriter, siyasi kriter, demografik kriter, sosyolojik kriter olarak sıralanabilir (Şahin, 2018, s.3). Kent tanımlaması için öncelikle kentte yaşayanların uğraş alanları önemlidir. Nitekim kentsel alanlarda yaşayan kişiler tarım dışı faaliyette bulunurlar. Sadece uğraş alanı olarak değil yönetim yapısı, toplumsal ilişkiler, kültürel alan- 
lar, nüfus yoğunluğu gibi birçok yönden kırsal alanlardan farklı olan yerler kent olarak tanımlanabilir (Başaran, 2007, s.209). Siyasal kritere göre kent belirli bir idari birim arasına kalan alanlar kent diğerleri kırsal alan olarak tanımlanır. Örneğin bir idari birim olarak il ve ilçenin kent olarak tanımlanması gibi... Demografik kriter açısından ise belirli nüfus aralığına kadar kırsal alan olarak nitelendirme yapılırken belirtilen nüfus oranını geçtikten sonra kent olarak nitelendirilmektedir. Örneğin 20 bin nüfusun üzerinde olan alanların kent olarak tanımlanması gibi... Ancak kent tanımlanması yapılırken bu iki ölçütte tam olarak kent tanımı yaptığını söyleyemeyiz (Erkan, 2010, s. 15). Bu kapsamda sosyolojik ölçütünde dikkate alınması gerekir. Sosyolojik kriter ile tanımlama yaparken kent ile kır arsındaki zıtlıklardan faydalanılır ve kavrama kentlileşme kavramı eklenir. Kentte yaşayan insanlar kentte özgü tavır ve davranışlar sergilediklerinden kırsal alanlarda yaşayan insanlardan farklılardır (Şahin, 2018: 5). Alternatif olarak bazı ülkeler, büyüklük, yoğunluk ve idari düzey dahil, ancak ayn zamanda kentsel istihdam (örneğin tarım dışı çalışanlar), tesisler (örneğin daha yüksek okullar), altyapı (örneğin caddeler, aydınlatma olanakları) olarak kabul edilebilecekleri göstergeleri de içeren birçok kritere göre kent tanımlaması yapmaktadır. Kent tanımları ülkeden ülkeye farklı şekilde oluşmakla birlikte zaman içerisinde de değişiklik göstermektedir (McGranahan ve Satterthwaite, 2014, s.7).

Kent kavramının ortaya çıkması sonucu kırsal alandan kentsel alanlara hızlı göçlerin olması kentleşme kavramının oluşmasına neden olmuştur. Günümüzde kentleşmenin kökenini bulmak için Ortadoğu ve Yakın Doğu'ya bakmak gerekmektedir. Kentleşme ile ilgili ilk veriler M.Ö. 3500'li yıllarda Irak yakınlarına dayanmaktadır. Başka bir ifade ile kentsel topluluklar yaklaşık 6000 yıl önce başlamış ve daha sonra Maya kültürü ile Meksika'da ve Çin ve Hindistan'da nehir havzalarında ortaya çıkmıştır (Peng v.d. 2000). Kentleşme olgusunun kökeni insanlığın kentlerde yaşamaya başlaması ve kentleri birer pazar yeri olarak kullanmasına dayandırılmakla birlikte kentleşmenin yaygın hale gelmesi sanayileşmeye dayanmaktadır. İngiltere'de başlayan sanayileşme hareketi, Almanya, Fransa, İsviçre ve Belçika gibi diğer Avrupa ülkelerine yayılmış ve bu ülkelerde kırsal alanlarda yaşayan nüfus kentsel alanların cazibesine kapılarak kırdan kentte doğru göç etmiştir (Bulut, 2005, s.33- 
34). Birleşmiş Milletlerin Kentsel Nüfus Projeksiyonuna göre 2010-2050 yılları arasında 944 milyon ek kent sakini daha Afrika'da kentlerinde ve Asya'da 1.449 milyon sakinde Asya kentlerine eklenecektir (McGranahan ve Satterthwaite, 2014, s.10).

Kingsley Davis (1962), kentleşmeyi insan yerleşimlerinin yayılma düzeninden kent merkezlerinde yoğunlaşma sürecine geçiş süreci olarak açıklamıştır. Bu tarım toplumundan sanayi toplumuna geçen topluluklar için döngüsel bir süreci ifade eder. Davis (1965) kentleşme sürecinin üç aşamadan oluştuğunu belirtmiştir. Birinci aşama, kırsal kesimde geleneksel toplumun tarımda ağırlıklı ve dağınık yerleşim düzenleriyle karakterize edilen ilk aşamasıdır. İkinci aşama, ekonominin yeniden yapılandırılmasının ve ulaşım, iletişim dahil olmak üzere sosyal ek sermaye yatırımlarının gerçekleştirildiği ivme aşamasını ifade eder. Üçüncü aşama, kentsel nüfusun \%70 veya daha fazla olduğu terminal aşaması olarak bilinir. Bu aşamada kentleşme seviyesi aşağı yukarı aynı ya da sabit kalır (Davis, 1962 ve 1965'den akt. Jaysawal ve Saha, 2014, s.60).

Kent Bilim Terimleri Sözlüğünde kentleşme, "iyileşme ve ekonomik gelişmeye koşut olarak kent sayısının artması ve kentlerin büyümesi sonucunu doğuran, toplumda artan oranda örgütleşmeye, uzmanlaşmaya ve insanlar arası ilişkilerde kentte özgü değişikliklere yol açan nüfus birikim süreci" olarak tanımlanmaktadır.

Kentleşmenin temel nedenlerinden birisi sanayi büyümesidir. Sanayideki büyüme ile birlikte istihdam olanakları artı ve bireyler kırsal alandan kentte doğru daha iyi istihdam olanaklarından dolayı göç etti. Kentsel nüfus oranındaki artış oranı \%30 olan Hindistan'da sınai büyüme oranı yıllık \%60 civarındadır. Diğer bir neden sosyal faktörlerdir. Kentlerde daha iyi yaşam olanakları, daha iyi eğitim tesisleri, statü ihtiyacı gibi sosyal faktörler insanları kentlere göç etmeye teşvik eder. Kırsal kesimde insanlar geçim kaynakları için çoğunlukla tarıma bağımlı olmak zorundadır. Kent ve kasabalarda, insanları kırsal alanlardan sürekli olarak daha iyi geçim elde etmek için çeken geniş iş fırsatları vardır. $\mathrm{Bu}$ nedenle, insanların büyük çoğunluğu, kentsel alanlar, halk sağlı̆̆ı, eğitim, ulaşım, spor ve rekreasyon, endüstriler ve iş girişimleri gibi tüm gelişimsel sektörlerde sayısız istihdam imkânına sahip olduklarından, iyi ücretli işlere erişmek için sık sık kentsel alanlara göç etmektedir. Bu 
nedenle, insanların büyük çoğunluğu, kentsel alanlar, halk sağlı̆̆1, eğitim, ulaşım, spor ve rekreasyon, endüstriler ve iş girişimleri gibi tüm gelişimsel sektörlerde sayısız istihdam imkânına sahip olduklarından, iyi ücretli işlere erişmek için sık sık kentsel alanlara göç etmektedir (Pawan, 2016, s.110).

Kırsal alanlardan kentlere göçün bir diğer nedeni teknolojik gelişmelerin kentlerde daha fazla imkân sağlamasıdır. Nitekim kentsel alanlar gelişmiş teknoloji daha iyi altyapı, iletişim, tıbbi tesisler, vb. ile karakterize edilir. Kentsel alanlarda, insanlar aynı zamanda konut, alışkanlık, tutum, giyinme, yiyecek ve inanç gibi yaşam biçimindeki değişiklikleri de kapsar (Pawan, 2016, s.111).

Kentleşme ekonomik gelişme açısından bir gösterge olmakla birlikte, kentlerde yeni sorunların ortaya çıkmasına neden olmaktadır. Kentsel yaşam alanlarında ortaya çıkan düşük yaşam kalitesinin nedenleri aşırı ya da çarpık kentleşmenin ortaya çıkardığı olumsuz dışsallıklar içinde yer alan trafik sıkışıklığı, su kaynaklı ve diğer bulaşıcı hastalıklar ve suç oranlarındaki artış olarak sıralanabilir. Yüksek konut maliyetleri aynı zamanda şehir yaşamının bir dezavantajıdır. Bir dışsallık değil, yüksek arazi maliyetlerinin kaçınılmaz bir sonucudur. Bununla birlikte arazi kullanımında kısıtlamalar gibi kentsel politikalar yapay olarak yaşam maliyetlerini artırabilir (Glaeser, 2013, s.20). Bu sorunlara ek olarak küresel ısınma, kirlilik, sanitasyon eksikliği, gecekondular ve aşırı kalabalıklaşmanın sonuçları, konut sorunu, işsizlik, uyuşturucu kullanımı, atık sorunu gibi sorunlarda kentleşmenin ortaya çıkardığı sorunlar arasına alınabilir (Pawan, 2016, s.111).

Şu anda, dünya nüfusunun \%50'sinden fazlası kentsel alanlarda yaşıyor ve dünya nüfusunun \%70'inin 2050 yılına kadar şehirlerde yaşayacağı tahmin ediliyor; Afrika ve Asya, diğer bölgelere göre daha hızlı kentleşiyor. Sağlıklı kent yaklaşımı, hem gelişmiş hem de gelişmekte olan ülkelerde kentleşme ve küreselleşme nedeniyle ortaya çıkan çok sayıda kentsel sağlık sorununu ele almaktadır (Sharma ve Nam, 2017, s.35).

\section{Sağlıklı Kent}

Kentler sosyal birer canlı varlıklar olarak nitelenebilir. Nitekim kentler, 
karmaşık bir toplumsal ilişkiler dizisi oluşturur ve şekillenirler (Aydın ve Belli, 2018, s.355). Kentler yaşayan organizmalar gibi doğup, büyüyen, nefes alan ve sürekli gelişebilen ve kaynakları geliştirebilen yapılardır (http://yalova.csb.gov.tr/saglikli-kent-nedir-kriterleri-nelerdir-haber169094). Bu gelişimin doğru bir şekilde gerçekleşmesi için kentin sağliklı olması gerekmekte ve bu gereklilikten dolayı kavram sadece kentleşme disiplinini içeren bir kavram olmaktan çıkarak birçok disiplini bir araya getirmektedir. Yaşayan bir organizmaya uygun olarak sağlıklı kent, "kentteki önemli değerleri yenilemek ve yeni mekânlar yaratmak", "kentin ulaşımında, konut alanlarında, yeşil alanlarında yeni, iyi fiziksel alanlar oluşturmak", "sosyal bütünleşmeyi oluşturmak ve geliştirmek", "toplumun gelişmesine ortam sağlamak", "sağlık servislerine yüksek seviyeli ulaşılabilirliği sağlamak", "yaşama imkânının sağlanması, ailesinin korunması, arkadaşları ile görüşebilmesi, yeme-içme ihtiyacını sağlayabilmesi, güvenli ve özgür bir biçimde yasama eylemlerini gerçekleştirmek" farklı aktivitelerin bir arada bulunduğu ortamı ifade eder (Başaran, 2007, s.208). Bunların gerçekleşebilmesi için sağlıklı kentte bulunması gereken sağlıklı binalar, açık alanlar ve onları oluşturan eleman ve bileşenlerden ihtiyaç vardır (Ok, 2007, s.213).

Bir kentte yaşayan bireylerin sağlık durumlarının belirlenmesinde biyolojik faktörlerin yanı sıra, yaşadıkları mekânın fiziksel, sosyal, kültürel ve ekonomik koşulları da önemli ölçüde etkili olmaktadır (Okçu ve Kaya, 2008, s.363). Nitekim sağlıklı kent, kentte yaşayan bireylerin sağlı̆̆ ile ilgilenmekle yetinmez aynı zamanda sosyal ve fiziksel çevrelerin oluşturulması ve bunların geliştirilmesi ve en yüksek kapasitelerine ulaşabilmeleri için bireyler arası dayanışma ruhunu geliştirilmesine olanak sağlayan ve toplumsal kaynakları sürekli olarak genişletin şehri ifade etmektedir. Bu kapsamda sağlıklı bir kent; çıtılar ile ilgilendiği gibi çıtıları oluşturan süreçlerle de ilgilenir. Kentleşme ile önü alınamaz sorunlar ortaya çıksa da her kent sağlıklı kent olmaya adaydır (İzmir Büyükşehir Belediyesi, http://skpo.izmir.bel.tr, E.T.: 20.12.2018).

Sağlıklı bir kent, belirli bir sağlık durumuna ulaşmış bir kent değildir. Aksine, sağlık bilincinde olan ve onu iyileştirmeye çalışan bir kenti ifade eder. Gereken şey, sağlığa bağllık ve bunu başarmak için bir süreç ve bu süreci uygulayacak bir organizasyondur. Sağlıklı ve aktif bir kent, yerleşik ve sosyal ortamlarda sürekli olarak fırsatlar yaratan ve geliştiren ve 
tüm vatandaşlarının günlük yaşamda fiziksel olarak aktif olmalarını sağlamak için topluluk kaynaklarını genişleten bir kenttir (Edwards ve Tsouros, 2008, s.3).

Sağlıklı bir kent, sürekli olarak bu fiziksel ve sosyal ortamları yaratan ve geliştiren ve insanların yaşamın tüm işlevlerini yerine getirmelerinde ve maksimum potansiyellerini geliştirmelerinde karşılıklı olarak birbirlerini desteklemelerini sağlayan topluluk kaynaklarını genişleten şehirdir. Sağlıklı şehrin amacı; sağlığı destekleyici bir ortam yaratmak, iyi bir yaşam kalitesi elde etmek, temel temizlik ve hijyen ihtiyaçlarını sağlamak, sağlık hizmetlerine erişim sağlamaktır (WHO, www.who.int, E.T.: 21.12.2018).

Kuruluşundan bu yana, Sağlıklı kentler kesin bir değerler kümesine dayandırılmıştır. Bunlar; sağlık ve refah hakkı; eşitlik ve sosyal adalet; cinsiyet eşitliği; Dayanışma; sosyal içerme ve sürdürülebilir kalkınma olarak ifade edilir. Sağlıklı kentler yaklaşımı sektörler arası işbirliği, toplumun katılımı ve güçlendirme ilkelerine dayanmaktadır (Tsouros, 2017, s.8).

Sağlıklı kent kavramına uygun şekilde sağliklı kentlerde bulunması gereken nitelikler 11 başlık altında sıralanabilir. Bunlar (Yalova Valiliği Çevre ve Şehircilik İl Müdürlüğü);

1. “Temiz, güvenilir bir fiziksel çevre (iyi kaliteli konutlar dahil)

2. Bugün dengeli olan ve uzun erimde (vadede) sürdürülebilecek bir ekoloji sistemi

3. Güçlü, dayanışma içinde bir toplum

4. Halkın kendi yaşam, sağlık ve gönencini (refahını) etkileyen kararlarda katılım ve denetimi

5. Bütün şehrin fertlerinin temel ihtiyaçlarının (yemek, su, barınak, gelir, güvenlik ve iş) karşılanması

6. Çeşitli temas, ilişki ve iletişim olanağı ile çeşitli kaynak ve tecrübeye ulaşılabilirlik

7. Geniş kapsamlı, yaşamsal ve yenilikçi bir kent ekonomisi

8. Geçmişe, şehir sakinlerinin kültürel ve biyolojik mirasına ve öbür küme ve kişilere bağlılığın desteklenmesi

9. Önceki özelliklerle uyumlu olanları geliştiren bir yapı

10. Optimum düzeyde herkese ulaşabilen uygun halk sağlığı ve hastalık bakım servisi 
11. Yüksek sağlık seviyesi (yüksek pozitif sağlık ve düşük hastalık servisi)

şeklinde sıralanabilir."

Kentleşmenin aşırı ve hızlı bir şekilde ortaya çıkması ile birlikte sağlıksız kent sayısı kentleşme hızında olduğu gibi düzensiz bir şekilde artış göstermektedir. Bu da kontrol edilmesi güç olan yeni kentsel sorunlara kapı aralıyor. Merkezi yönetimler göçü tersine çevirmek için çeşitli önlemlere başvursa da bu önlemler yetersiz kalmaktadır. Kentsel nüfusu azaltmak ya da göçü tersine döndürmek önemli çözüm önerileri arasında sayılsa da kentlerde ortaya çıkan sağlıksız ortamların nasıl düzeltileceği üzerinde de ayrıca durulmalıdır (Susmaz ve Ekinci, 2009, s.31). Bu kapsamda kentleşmenin ortaya çıkardığ1 sorunlara bir çözüm olarak düşünülen sağlıklı kentler ile ilgili ilk uluslararası çalışmanın 1972 yılında gerçekleştirilen Stockholm Konferansı ile olmuştur. Bu konferansın çıktılarından olan Stockholm Bildirgesi'nin 16. maddesinde "temel insan haklarına ön yargısız olarak, ilgili hükümetlerce uygun bulunan demografi politikaları; çevre ve kalkınma üzerinde olumsuz etkileri olan nüfus artış hızı veya aşırı nüfus yığılmaları ile düşük nüfus yoğunluğunun insan çevresinin gelişmesini veya kalkınmayı engelleyebileceği bölgelerde uygulanmalıdır" denilerek sürdürülebilir kentleşme olgusu üzerinden sağlıklı, planlı yaşanabilir kentlere vurgu yapılmıştır (Karakurt Tosun, 2009). 1987 yılında Bruntland Raporu ile dünya gündemine giren sürdürülebilir kalkınma kavramı da sağlıklı kentin oluşumunda önemli bir ivme kazandırmıştır. Nitekim sürdürülebilir kalkınma gelecek kuşakların ihtiyaçları gözü önüne alarak bugünün ihtiyaçlarını sağlıklı ve dengeli bir şekilde karşılamak olarak tanımlanmaktadır (Altuntaş, 2012, s. 136). Görüldüğü üzere sağliklı ve dengeli bir tüketimden bahsedilmektedir. Bu kapsamda her alanda olduğu gibi kentlerde de sağlıklı ve dengeli bir ortam oluşturarak gelecek kuşakların hakkının korunması sağlanabilir. Bu kapsamda sağlıklı kent kavramı ile sürdürülebilir kentler arasında doğrudan bir ilişki vardır. Kentlerde sürdürülebilirliği sağlayabilmek için öncelikle kentin nüfus artışının ve kent sayısındaki artışın düzenli olması gerekmektedir. Hızlı ve aşırı kentleşmiş ülkelerde sağlıklı kentlerin oluşması güçtür.

Sağlıklı kent kavramının da ortaya çıkışı da dünya üzerindeki yoğun kentleşmeye bağlıdır. Nitekim kavramı ilk olarak Dünya Sağlık Örgütü 
tarafından 1985 yılında Kanada'da uygulama bulmuştur (Özcan, 2007, s. 692). DSÖ Avrupa Sağlıklı Şehirler Programı, DSÖ Herkes için Sağlık Stratejisinin ve Sağlı̆̆ın Teşviki için Ottawa Şartı'nın ilkelerinin uygulanmasına yönelik yerel bir temel oluşturmak amacıyla 1986 yılında kurulmuştur. O zamandan beri güçlü bir Avrupa çapında katılımla birlikte küresel bir hareket haline gelmiştir.

DSÖ Avrupa Sağlıklı Şehirler Ağı, yerel yönetimlerin politik taahhüt, kurumsal değişim, kapasite geliştirme, ortaklık temelli planlama ve yenilikçi projeler süreci ile sağlı̆̆ı geliştirme konusundaki ilgisini çekmektedir. Sağlık ve kentsel yoksulluktaki eşitsizliğe, savunmasız grupların gereksinimlerine, katılımcı yönetişime ve sağlığın sosyal, ekonomik ve çevresel belirleyicilerine özel vurgu yaparak kapsamlı ve sistematik politika ve planlamayı teşvik eder. Kentsel ekonomik, yenilenme ve kalkınma çabalarına sağlık konularını dahil etmek için çaba göstermektedir (Edwards ve Tsouros, 2008, s.3).

Sağlıklı kentler projeleri sağlığa bağlılık, politik karar verme, sektörler arası eylem, halk katılımı, yenilikçi yaklaşımlar, sağlıklı kamu politikası olmak üzere altı ortak özelliğe sahiptir (WHO Regional Office for Europe, 1997: 13-14). Sağlıklı kentler hareketinin stratejik hedefleri aşağıdaki gibidir (Şarköy Stratejik Vizyon Planı, 2011, s.8):

- "Sağlık, yoksulluk ve savunmasız grupların ihtiyaçlarını dikkate alarak yerel seviyede sağlıklı ve sürdürülebilir gelişme hedefli politika ve eylemleri desteklemek,

- Sağlık gelişimi, kamu sağlığı ve kentsel yenileme konuları bağlamında merkezi-yerel işbirliğini sağlayarak ulusal düzeyde Sağlıklı Kentler yaklaşımını güçlendirmek,

- Sağlığın teşviki için politika ve uygulama uzmanlığı geliştirmek, gerekli bilgi ve yöntemleri oluşturmak,

- Hareket ağına katılan şehirler arasında bütünlük, iş birliği ve kuvvetli bağların kurulmasını sağlamak,

- Kentsel konularla ilgilenen diğer kurumlarla ortaklıklar kurarak sağlık konusunun savunulmasında aktif rol oynamak."

1992 Kopenhag Konferansı, Sağlıklı kentler hareketi için önemli bir fırsattır. Konferanstan siyasi destek oluşturma, altyapı oluşturma ve politika ve uygulamada yenilik getirme konularında edinilen kritik dersler ortaya çıkmıştır (WHO Regional Office for Europe, 1997, s. 11) Sağliklı 
kentler ile ilgili bir diğer gelişme 1997 yılında gerçekleştirilen Dördüncü Uluslararası Sağlığın Geliştirilmesi Konferansı'dır. Bu konferans sonucunda Jakarta Sağlı̆̆ın Teşviki Deklarasyonu kabul edilmiştir. Jakarta Sağlığın Teşviki Deklarasyonu, gelecek yüzyıla kadar sağlığın teşviki ve geliştirilmesi için bir vizyon ve odaklanma sunar. Dördüncü Uluslararası Sağlık Teşvik Konferansı'na katılanların, 21. yüzyılda sağlık belirleyicileriyle mücadele etmek için mümkün olan en geniş kaynak yelpazesinden yararlanmaları konusundaki kararlılıklarını yansıtmaktadır (WHO, www.who.int, E.T.: 28.12.2018). Ottowa Şartı ve Jakarta Deklarasyonu, sağlı̆̆ın teşviki ve geliştirilmesi ile ilgili vizyoner açklamalardan oluşur. Dünya Sağlık Örgütü ve Uluslararası Sağlığı Geliştirme Konferanslarına katılanlara, sağlı̆̆ın teşviki açısından davranış değişikliğinin ötesine beklentiler içerir (Leeuw, 2001, s.36).

Sağlıklı kentlerin misyon ve niteliklerini 21. yüzyıl bağlamına çevirirken, ana hedefler aşağıdaki gibi ifade edilebilir (Tsouros, 2017, s.10):

1. Tüm yerel politikalarda sağlığı ve eşitliği teşvik etmek ve Sürdürülebilir Kalkınma Hedefleri (Sustainable Development Goals) gündemine tam olarak uymak;

2. Sağlıkta Sosyal Belirleyiciler (Social Determinants of Health) yaklaşımıyla sağlıktaki eşitsizliklerin ele alınması;

3. Aktif yaşam dahil olmak üzere sağlıklı yaşam tarzlarını destekleyen ortamlar oluşturmak;

4. Evrensel sağlık sigortası ve tüm vatandaşların ihtiyaçlarına erişilebilir ve duyarlı sosyal hizmetler sağlamak;

5. Sağlı̆̆ geliştirme ve sağlık okuryazarlı̆̆ına yatırım yapmak;

6. Çocuklar için hayata sağlıklı bir başlangıç yapmak ve göçmenler, işsizler ve yoksulluk içinde yaşayan insanlar gibi dezavantajlı gruplara destek sağlamak;

7. Obezite, sigara, sağlıksız beslenme ve fiziksel hareketsizlik konularına özel olarak odaklanarak hastalık önleme programlarının güçlendirilmesi;

8. Sağlıklı kentsel planlama ve tasarımın desteklenmesi;

9. Yeşil, temiz, çocuk dostu ve yaşlı dostu şehir ortamlarına yatırım yapmak;

10. Topluluğun güçlendirilmesini, katılımını ve esnekliğini desteklemek ve sosyal içermeyi ve topluma dayalı girişimleri teşvik etmek; 
11. Şehrin halk sağlı̆g acil durumlarına cevap verme kapasitesinin güçlendirilmesi.

\section{Misyon ve Vizyon}

Stratejik yönetim anlayışının kamu yönetiminin de uygulanmaya başlaması ile birlikte özel örgütlenmelerin bir aracı olan misyon ve vizyon kavramları kamu kurumlarının stratejik planlarının temel öğesi olmuştur. Nitekim vizyon ve misyonu geliştirmek stratejik yönetim sürecinin bir parçasıdır. Stratejik yönetim süreci genellikle dört temel unsuru içeren bir model olarak tanımlanır: çevresel tarama, strateji oluşturma, strateji uygulama ve değerlendirme ve kontroldür. Vizyon ve misyonun gelişimi, strateji formülasyonunun bir parçasıdır. Bu adım sadece vizyon ve misyon gelişimini değil aynı zamanda stratejik hedeflerin ve strateji geliştirmenin özelliklerini de içerir (Papulova, 2014, s.12). Bu durumda strateji, misyonun belirlediği çizgilere sadık kalarak, kaynakların kimlere, hangi birimlere ve ne ölçüde dağıtılması gerektiğini ifade eden bir anlam taşıyacaktır. Stratejik planların temelinde misyon bildirimi yatmaktadır (Çetin, 2009, s. 98).

Bir örgütte stratejik plan oluşturulmadan önce misyon ifadesinin tanımlanması gerekir (Papulova, 2014, s.13). Misyon örgütler için; yaptığı işleri, değerleri, inançları, varoluş sebepleri ve kendilerinin diğer örgütlenmelerden farkını ortaya koyabilmek için izlemeleri gereken stratejileri gösteren bir yol haritasıdır (Muslu, 2014, s.15). Türk Dil Kurumunda göre misyon kavramının karşılı̆̆ görevdir (www.tdk.gov.tr, 02.01.2019). Kuruluş, var olma nedenini misyonunda belirler. Misyonda kuruluşun gerçekleştirdiği faaliyetler, bunları gerçekleştirirken izlediği yol ve yöntemler ile bu faaliyetlerin kimler için gerçekleştirildiği net bir biçimde yer alır. Misyon tebliği, kuruluşun gerçekleştirdiği hizmet ve çalışmaları içeren çatı ifadedir. Misyon; görevlileri, yetkilileri ve ortakları yönlendirici bir unsur olmakla birlikte, aynı zamanda ulaşılmak istenen yeri, yani hedefleri ve ilkeleri de göstermektedir. Bu nedenle hedefe ulaşmayı sağlayacak bir stratejiyi de tanımlamaktadır (Ocak v.d., 2016, s.505).

Vizyon, misyon ve ilgili hedefler için sıçrama tahtası olan stratejik bir yön sağlar. Bu söylem unsurunun var olmasına rağmen, bir vizyon 
ifadesinin bir misyon ifadesinin aksine, oryantasyonuyla ilgili çok büyük bir fikir birliği vardır. Mantıken hiçbir kuruluş statik kalmak istemez; Bir örgütün kurucusunun sahip olduğu sık sık "hayal" olarak adlandırılan şeye rastlamak nadir değildir. Bir vizyon, kuruluşlarının arzu edilen gelecekteki durumlarının güçlü ve çekici zihinsel imajlarını oluşturmak içindir (Darbi, 2012, s.96). Vizyon genellikle geleceğin bir resmi olarak görülür. Mükemmelliğin bir resmi, olan vizyon bir örgüt veya kuruluşun gelecekte oluşturmak istediği en iyi şey olarak tanımlanabilir. Genellikle, biz vizyon ifadesi anlaşılması kolay, hatırlaması kolay, olumlu, motivasyonlu, ilham veren, çekici, zorlu, geleceğe yönelik olmalıdır (Papulova, 2014, s.13). Vizyona, spesifik hisler ve ilkelere sadık kalarak oluşturulan bir eylem planıla erişilir (Çetin, 2009, s.99). Vizyon, uzun vadelidir. Dolayısıyla hedeflere ulaşmak daha uzun sürecektir. Bundan dolayı vizyon, ciddi çevresel etkilere maruz kalmadıkça veya tamamıyla gerçekleştirilmediği sürece değiştirilmez (Ocak v.d., 2016, s.505). Vizyonun iki temel bileşeni vardır; temel bir ideoloji ve vizyoner gelecek. Temel ideoloji, örgüt varlığının sebeplerini, sürekli özelliklerini ve özgün kimliğini verir. Vizyoner gelecek öncelikle kuruluşun durumunu 10 ve 30 yıl sonra tanımlar. Organizasyonun kendisi için teşvik edici olduğu kadar zorlayıcı olmalı, çünkü gelecekteki tüm aktiviteler buna dayanıyor (Tankovic, 2013, s.332).

Vizyon ulaşılmak istenen nokta, misyon ise teşkilatın var olma gerekçesidir (Çetin, 2009, s.99). Nitekim misyon, yön belirlememizi sağlayan ve nereye gitmek istediğimizi gösteren vizyonun aksine, örgütün faaliyet göstereceği alanı tanımlar. Bu nedenle misyon, şimdiki ve gelecekteki talimatlarla ilgilidir. Misyon, vizyonun aksine, uzak geleceğe yönelik değildir. Misyonun kendisinin yerleşik bir zaman boyutu olmadığını söylemek tercih edilir (Papulova, 2014, s.13). Misyon, niteliği ön planda tutarken vizyonda bu durum söz konusu değildir. Misyonun odak noktası nicellik ve erişilebilirlik olmaktadır. Bunun sebebi ise insanları teşvik eden şeyin, ölçülebilir ve erişilebilir hedefler olmasıdır. Gerçekten uzak, erişilme imkanı olmayan ve ne olduğu nicel olarak belli olmayan hedefler ise insanların uzak durmak istediği hedeflerdir (İnce, 2015, s.146). Bununla birlikte vizyon ve misyon birbirine bağlı ve iç içe geçmiş durumdadir (Tankovic, 2013, s.332). 


\section{Büyükşehir Belediyeleri ve Sağlıklı Kent}

Türkiye'de sağlıklı kentler ile ilgili olan kuruluş Türkiye Sağlıklı Kentler Birliği'dir. Türkiye Sağlıklı Kentler Birliği 6. Dünya Sağlık Örgütü Bölge Ofisi'nde, 66 ülkede faaliyette bulunan Sağlıklı Kentler Projesi'nin Türkiye temsilcisi olarak, 2005 yılında Bursa Büyükşehir Belediyesi öncülügünde kent sağlığını yaşanabilir, çağdaş kentler oluşturmak amacıyla kurulmuştur (T.C. Sağlık Bakanlığı, Temel Sağlık Hizmetleri Genel Müdürlüğü, 2011, s.107). Türkiye Sağlıklı Kentler Birliği Birlik Tüzüğü İçişleri Bakanlığı tarafından onaylanmış ve 22.12.2004 tarihli Resmi Gazete'de yayınlanarak yürürlüğe girmiştir (Türkiye Sağlıklı Kentler Birliği, www.skb.org.tr, 20.12.2018). Türkiye'de Sağliklı Kentler Birliği'ne üye olan 17 büyükşehir belediyesi bulunmaktadır. Bunlar; Antalya Büyükşehir Belediyesi, Aydın Büyükşehir Belediyesi, Balıkesir Büyükşsehir Belediyesi, Bursa Büyükşehir Belediyesi, Denizli Büyükşehir Belediyesi, Erzurum Büyükşehir Belediyesi, Hatay Büyükşehir Belediyesi, İstanbul Büyükşehir Belediyesi, İzmir Büyükşehir Belediyesi, Kahramanmaraş Büyükşehir Belediyesi, Kocaeli Büyükşehir Belediyesi, Mardin Büyükşehir Belediyesi, Mersin Büyükşehir Belediyesi, Muğla Büyükşehir Belediyesi, Ordu Büyükşehir Belediyesi, Samsun Büyükşehir Belediyesi, Trabzon Büyükşehir Belediyesidir (Türkiye Sağlıklı Kentler Birliği Tüzüğü, Md. 4.).

Sağlıklı Kentler Birliği Meclisi'nin 15/05/2010 tarih ve 6 sayılı kararıyla Sağlıklı Kentler Birliği'ne üye olacak şehirler Belediye Meclis Kararları ile (Türkiye Sağlıklı Kentler Birliği);

- Sağlıklı Kentler Birliği Tüzügüün̈n, DSÖ 2014 Sağlıklı Şehirler Atina Deklarasyonunun kabul edilmesi,

- Sağlık alanındaki eşitsizlikleri azaltmak, sağlıklı yaşam şekillerini ve sağlık okuryazarlığını geliştirmek, hassas grupları desteklemek ve sağlık konusunu şehir planlama ve imar uygulamaları içerisine yerleştirmek amacıyla şehirdeki tüm sektörlerle ve sivil toplumla birlikte çalışmalar yapılması ve sağlıklı bir şehir oluşturmak için çalışmalar yürütülmesi,

- Biri Belediye Başkanı olmak üzere 2 asil 2 yedek üyenin Birlik Meclisinde görevlendirilmesi, 
- Üye olacak Belediye tarafından Sağlıklı Kentler Proje Koordinatörü atanması, proje ortaklığı oluşturulması ve Sağlıklı Kentler Proje Ofisi kurulması ile ilgili karar alınması,

- Üye Olacak Belediye tarafından Şehir Sağlık Profili hazırlaması, Yıllık Faaliyet Programı hazırlaması,

- Birlik Başkanlığı'na gönderilmek üzere yıllık raporlama yapması, Birlik Toplantılarına düzenli katılımın sağlanması ve üye şehirlerle tecrübelerin paylaşılması ve üyelik aidatlarının ödenmesi hususlarında karar almalıdır.

DSÖ Sağlıklı Kentler Projesi'nde yer almanın yararları şu şekilde siralanmaktadır (Aycan, https://seferaycan.wordpress.com, 23.12.2018);

- "Halk sağlığı konularında bilincin artması ve ilgili uluslararası hareketlerin bir parçası olmak,

- Milenyum 21 ilkeleri ve uygulamaları içindeki "Herkes İçin Sağlık" hedefinde yerel çalışma olarak yer almak,

- İçinde etkin uygulamaların geliştirileceği uluslararası bir ortam oluşturmak,

- Ortaklık projeleri için Avrupa fonu gibi ekstra kaynaklar için uygun güç sağlamak,

- Türkiye'deki Sağlıklı Şehir Ortaklığı çalışmalarını geliştirmek,

- Sağlık sorunları üzerine diğer üye şehirlerle bilgi ve uygulama deneyimi paylaşmak için bir ağ oluşturmak,

- Sağlık ve sağlıktaki hakça olmayan dağılımın sosyal etkileri ile ilgili araştırma ve geliştirmelere ulaşılabilmek,

- Kentte bütün tarafların, kent için katılımcı ve demokratik çalışma kültürünü geliştirmelerini sağlamaktır."

\section{Büyükşehir Belediyelerinde Yasal Mevzuat Çerçevesinde Sağlıklı Kentler}

1982 Anayasasının 56. Maddesi sağlık ve çevre hakkı kavramlarını içermektedir. Buna göre "Herkes, sağhlklı ve dengeli bir çevrede yaşama hakkına sahiptir.

Çevreyi geliştirmek, çevre sağhlğ̆ın korumak ve çevre kirlenmesini önlemek Devletin ve vatandaşlarm ödevidir. 
Devlet, herkesin hayatını, beden ve ruh sağ̆lğg içinde sürdürmesini sağlamak; insan ve madde gücünde tasarruf ve verimi artırarak, işbirliğini gerçekleştirmek amacıyla sağlık kuruluşların tek elden planlayıp hizmet vermesini düzenler.

Devlet, bu görevini kamu ve özel kesimlerdeki sağlık ve sosyal kurumlarndan yararlanarak, onlarn denetleyerek yerine getirir.

Sağllk hizmetlerinin yaygın bir şekilde yerine getirilmesi için kanunla genel sağlık sigortası kurulabilir."

56. madde sağlıklı ve dengeli bir çevrede yaşama hakkını tanımıştır. Bunun sağlanması için hem vatandaşlara hem de devlete yükümlülük altına sokmuştur. Ancak Anayasada 65. Madde ile "Devlet, sosyal ve ekonomik alanlarda Anayasa ile belirlenen görevlerini, bu görevlerin amaçlarma uygun öncelikleri gözeterek malî kaynaklarının yeterliliği ölçüsünde yerine getirir." denerek devletin ödevlerini yerine getirirken bazı sınırlamalar olabileceğini ortaya koymuştur.

Anayasaya uygun olarak 5216 sayılı Büyükşehir Belediye Kanunu'nda belediyenin görevlerini sayarken çevre hakkını dikkate almıştır. Kanunun 7. maddesinde büyükşehir belediyelerinin görevleri sayılırken sürdürülebilir kalkınma ve çevre korumaya özel önem verilmiştir. 7. Maddenin i fıkrası şöyledir; "Sürdürülebilir kalkınma ilkesine uygun olarak çevrenin, tarm alanlarmm ve su havzalarını korunmasın sağlamak; ă̆açlandırma yapmak; hafriyat topră̆ı, moloz, kum ve çakıl depolama alanlarını, odun ve kömür satış ve depolama sahaların belirlemek, bunların taşınmasında çeore kirliliğine meydan vermeyecek tedbirler almak; büyükşehir katı atık yönetim plânını yapmak, yaptırmak; katı atıkların kaynakta toplanması ve aktarma istasyonuna kadar taşınması hariç katı atıkların ve hafriyatın yeniden değerlendirilmesi, depolanması ve bertaraf edilmesine ilişkin hizmetleri yerine getirmek, bu amaçla tesisler kurmak, kurdurmak, işletmek veya işlettirmek; sanayi ve tıbbî atıklara ilişkin hizmetleri yürütmek, bunun için gerekli tesisleri kurmak, kurdurmak, işletmek veya işlettirmek; deniz araçlarının atıkların toplamak, toplatmak, arıtmak ve bununla ilgili gerekli düzenlemeleri yapmak." Madde hükmünde görüldüğ̈̈ üzere çevrenin korunmasında sürdürülebilir kalkınma ilkesi temel alınmıştır. Korunması gereken alanlar belirlenirken çevre, tarım alanları ve su havzaları sayılmış ve katı atık konusu üzerinde önemle durulmuştur. 
Sağlıklı kentler açısından bir diğer önemli konu olan Tarihi ve kültürel çevrenin korunması görevi de 5216 sayılı Kanun'da yer bulmuştur. Buna göre Kanunun 7. Maddesi o fikrasında "Kültür ve tabiat varlikları ile tarihî dokunun ve kent tarihi bakımından önem taşıyan mekânların ve işlevlerinin korunmasını sağlamak, bu amaçla bakım ve onarımın yapmak, korunması mümkün olmayanları aslına uygun olarak yeniden inşa etmek" görevi sayılmıştır.

Sağlık ile ilgili olarak büyükşehir belediyelerine "sağllk merkezleri, hastaneler, gezici sağlık üniteleri ile yetişkinler, yaşlllar, engelliler, kadınlar, gençler ve çocuklara yönelik her türlü sosyal ve kültürel hizmetleri yürütmek, geliştirmek ve bu amaçla sosyal tesisler kurmak, meslek ve beceri kazandırma kursları açmak, işletmek veya işlettirmek, bu hizmetleri yürütürken üniversiteler, yüksek okullar, meslek liseleri, kamu kuruluşları ve sivil toplum örgütleri ile işbirliği yapmak" görevi verilmiştir.

Büyükşehir belediyelerinin eğitim, sağlık, planlama gibi birçok görevi 5216 sayılı Kanunun 7. Maddesinde sayılmıştır. Konunun çok fazla dağılmaması adına bu hükümlere yer verilmemiştir.

Büyükşehir belediyeleri son dönemde önemli bir noktaya gelmiştir. Çünkü 6360 sayılı Kanun ile birlikte büyükşehir belediyeleri sınırları il mülki sınırları olarak belirlenmiştir. Bu kapsam büyükşehir belediye sınırları içerisindeki belde belediyeleri ve köylerin tüzel kişiliği kaldırılarak bağlı bulunduğu ilçenin mahallesine dönüştürülmüştür (Belli ve Aydın, 2017, s.411). Kanun ile kırsal alan ile kentsel alan arasındaki idari fark ortadan kalkmış ve büyükşehir belediyeleri tüm alanlara hizmet götürmek zorunda kalmıştır. Bu kapsamda sağliklı kentler açısından büyükşehirlerin özel önemi bulunmaktadır.

\section{Türkiye'deki Büyükşehir Belediyelerinin Sağlıklı Kentler Açısından Vizyon ve Misyonlarının Analizi}

Sağlıklı kentlerde bulunması gereken değerler ve özellikler çalışmanın kavramsal çerçevesinde geniş şekilde yer bulmuştur. Bu özellik ve değerlerin hangi oranda vizyon ve misyona yansıdığını bulmak üzere nitel araştırma yöntemlerinden faydalanılmıştır. Araştırma için nitel araştırmanın doküman inceleme yöntemi tercih edilmiştir. Doküman incelemesi, araştırmanın konusu olan dokümanların, belgelerin ve 
metinlerin detaylı bir biçimde incelenmesi ve analizi olarak ifade edilebilir (Yıldırım ve Şimşek, 2004, s.153). Bu çalışmada, doküman inceleme yöntemiyle büyükşehir belediyelerinin vizyon ve misyon tanımları, stratejik planlarından ve internet sitelerinden elde edilmiştir.

Araştırmanın çalışma evreninde 30 büyükşehir belediyesi bulunmaktadır. Araştırmada örneklem alma yoluna gidilmeden evrenin tamamına ulaşılmaya çalışılmıştır. Sonuç olarak 29 büyükşehrin stratejik planına ulaşılmış sadece Mardin Büyükşehir Belediyesinin vizyon ve misyonuna ulaşılamamıştır. Araştırmanın verileri doküman incelemesi tekniği ile toplanmıştır. Toplanan veriler içerik analizi tekniği ile analiz edilmiştir. Yazılı olarak yer alan misyon, vizyon ifadeleri belli başlıklar altında toplanarak frekansları çıkarılmıştır. Son olarak frekansları çıkarılan ifadelerden birbirine yakın olarak gruplandırılarak alt temalar oluşturulmuştur. Vizyon ve misyon ifadelerinde sağlıklı kente ilişkin ifadelerin bulunup bulunmadığını bulmak için eşitlik, adalet, hesap verilebilirlik, kültür, tarih, sürdürülebilirlik, katılım, plan, çevre, sağlık ve sağlık kodunun alt kodu yaşanabilir kodları kullanılmıştır.

\section{Misyon İfadelerinde Sağlıklı Kent}

Misyon ifadeleri incelenirken" Toplumsal değerlerimiz" ifadesi kültür ifadesi ile kodlanmıştır. "sistemli alt yapı, duyarlı kentsel dönüşüm" ifadesi plan ifadesi ile kodlanmıştır. "birlikte yönetim anlayışı" ve "tüm paydaşlarımız" ifadeleri katılım ifadesi ile kodlanmıştır. "gerekli alt yapı ve üst yapı hizmetlerini", " Ankara Halkının yaşamsal alanlardaki peyzaj ve yeşil alan gereksinimlerinin en yüksek düzeyde karşılanması, bu alanlarının bakım, onarım ve korunması hizmetlerini gerçekleştirmek" ve "ekolojik dengeyi korumak" ifadeleri çevre kodu ile kodlanmıştır. "tarafsız, güvenilir"; "dengeli bir şekilde sağlamak"; "ilçe belediyeleri ile eşgüdüm içinde"; "tarafsız" ifadeleri eşitlik ifadesi ile kodlanmıştır. "Kentimizde yaşayanların refah ve mutluluğunu artıracak belediyecilik hizmetlerini, ekonomik, etkili ve verimli bir şekilde sunmak", "yüksek kalite standartlarında yaşam düzeyi sunarak", “yaşamaktan mutluluk duyulacak bir şehir", "halkın gündelik yaşamını kolaylaştırmak", "insanların yaşadıkları şehirden zevk almalarını sağlamak." Ve "yaşanabilir" ifadeleri yaşanabilir ifadesi ile kodlanmıştır. An- 
talya Büyükşehir Belediyesi'nin misyon ifadesinde belirlediğimiz kodların hiçbiri bulunmuyor. Ancak misyondaki "halkının ve ziyaretçilerinin yaşamını kolaylaştıran ve değerli kılan en kaliteli yerel hizmeti vererek; huzurlu, güvenli, gelişmiş, estetik bir şehirde yaşama imkânı" yaşanabilir kodu ile ifade edilmiştir.

Tüm büyükşehir belediyelerinin misyon ifadeleri ile sağlıklı kent ifadelerinin durumunu incelemek için kod-matris tarayıcısı ile aşağıdaki tablo oluşturulmuştur.

Tablo 1. Misyon Ífadeleri İçin Kod-Matris Tarayıcısı

\begin{tabular}{|c|c|c|c|c|c|c|c|c|c|c|c|c|}
\hline & 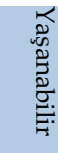 & 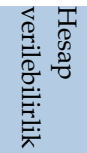 & $\begin{array}{l}\overrightarrow{0} \\
\frac{2}{0} \\
\frac{0}{0}\end{array}$ & 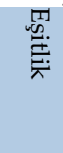 & 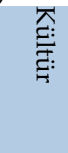 & 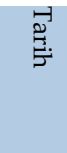 & 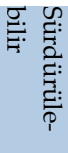 & $\frac{\vec{J}}{\tilde{J}}$ & $\begin{array}{l}\text { त्ત } \\
\stackrel{\Xi}{\Xi} \\
\Xi\end{array}$ & $\stackrel{0}{3}$ & 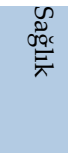 & $\frac{\text { 웅 }}{\frac{0}{0}}$ \\
\hline Adana & 0 & 0 & 1 & 0 & 0 & 0 & 0 & 1 & 0 & 0 & 0 & 2 \\
\hline Ankara & 0 & 0 & 0 & 0 & 0 & 0 & 1 & 0 & 0 & 1 & 0 & 2 \\
\hline Antalya & 1 & 0 & 0 & 0 & 0 & 0 & 0 & 0 & 0 & 0 & 0 & 1 \\
\hline Aydın & 1 & 0 & 0 & 0 & 0 & 0 & 1 & 0 & 0 & 0 & 0 & 2 \\
\hline Balıkesir & 1 & 0 & 1 & 1 & 0 & 0 & 0 & 0 & 0 & 1 & 0 & 4 \\
\hline Bursa & 0 & 0 & 0 & 1 & 0 & 0 & 1 & 0 & 2 & 0 & 0 & 4 \\
\hline Denizli & 1 & 0 & 1 & 1 & 0 & 1 & 0 & 0 & 0 & 1 & 1 & 6 \\
\hline Diyarbakır & 1 & 0 & 0 & 0 & 0 & 0 & 0 & 0 & 0 & 0 & 0 & 1 \\
\hline Erzurum & 1 & 0 & 0 & 0 & 0 & 0 & 1 & 1 & 0 & 0 & 0 & 3 \\
\hline Eskişehir & 1 & 0 & 0 & 0 & 0 & 0 & 0 & 0 & 0 & 0 & 0 & 1 \\
\hline Gaziantep & 1 & 0 & 0 & 1 & 1 & 1 & 0 & 0 & 1 & 0 & 0 & 5 \\
\hline Hatay & 1 & 0 & 1 & 0 & 1 & 0 & 0 & 0 & 1 & 1 & 0 & 5 \\
\hline İstanbul & 0 & 0 & 0 & 0 & 1 & 0 & 0 & 0 & 0 & 0 & 0 & 1 \\
\hline İzmir & 1 & 0 & 0 & 0 & 1 & 1 & 0 & 2 & 1 & 1 & 0 & 7 \\
\hline Kahramanmaraş & 0 & 0 & 1 & 0 & 1 & 1 & 0 & 0 & 0 & 1 & 0 & 4 \\
\hline Kayseri & 0 & 0 & 0 & 0 & 1 & 1 & 0 & 0 & 0 & 0 & 0 & 2 \\
\hline Kocaeli & 1 & 0 & 1 & 0 & 1 & 0 & 0 & 0 & 1 & 1 & 0 & 5 \\
\hline Konya & 1 & 0 & 1 & 0 & 1 & 1 & 0 & 1 & 1 & 0 & 0 & 6 \\
\hline Malatya & 1 & 1 & 1 & 1 & 0 & 0 & 0 & 0 & 0 & 1 & 0 & 5 \\
\hline Manisa & 1 & 0 & 0 & 0 & 0 & 0 & 0 & 0 & 0 & 0 & 0 & 1 \\
\hline Mardin & 0 & 0 & 0 & 0 & 0 & 0 & 0 & 0 & 0 & 0 & 0 & 0 \\
\hline Mersin & 1 & 0 & 1 & 0 & 2 & 1 & 0 & 1 & 1 & 1 & 0 & 8 \\
\hline Muğla & 0 & 1 & 0 & 0 & 0 & 0 & 0 & 0 & 0 & 0 & 0 & 1 \\
\hline Ordu & 1 & 0 & 1 & 0 & 0 & 0 & 0 & 0 & 1 & 0 & 0 & 3 \\
\hline Sakarya & 1 & 0 & 0 & 0 & 0 & 0 & 0 & 0 & 0 & 1 & 0 & 2 \\
\hline Samsun & 0 & 0 & 0 & 1 & 0 & 0 & 0 & 0 & 0 & 0 & 1 & 2 \\
\hline Şanlıurfa & 1 & 0 & 1 & 0 & 0 & 0 & 0 & 0 & 1 & 0 & 0 & 3 \\
\hline Tekirdağ & 1 & 0 & 0 & 1 & 0 & 0 & 0 & 0 & 1 & 1 & 0 & 4 \\
\hline Trabzon & 1 & 0 & 0 & 1 & 1 & 2 & 0 & 0 & 1 & 0 & 0 & 6 \\
\hline Van & 1 & 0 & 0 & 0 & 1 & 1 & 0 & 0 & 0 & 0 & 0 & 3 \\
\hline TOPLAM & 21 & 2 & 11 & 8 & 12 & 10 & 4 & 6 & 12 & 11 & 2 & 99 \\
\hline
\end{tabular}


Büyükşehir belediyelerinin misyonları içinde en fazla yer alan ifade yaşanabilir, yaşam kalitesi, daha güzel bir kent gibi ifadelerin yer aldığ 1 yaşanabilir ifadesidir. Katılımcılık, katılım, katılımcı gibi ifadelerin yer aldığ1 katılım ifadesidir. Yaşanabilir ifadesinden donra en fazla kullanılan ifade katılım ve kültür ifadeleridir. Bu ifadelerden sonra Adalet ve çevre ifadeleri 11 defa kullanılmıştır. Tarih ifadesi ise 10 defa kullanılmıştır. Misyonlar içerisinde en az kullanılan ifadeler sağlık ve hesap verilebilirlik ifadeleridir.

Sağlıklı kenti ifade eden kodların en fazla bulunduğu büyükşehir belediyesi İzmir'dir.

Mersin Büyükşehir Belediyesi'nin misyonu “Mersin'in özgün kültürel kimliğini korumak, yaşam kalitesini yükseltmek, tarihi, kültürel ve doğal güzelliklerine sahip çıkmak, kaynakları planlı, programlı ve verimli kullanmak, ekolojik dengeyi korumak, katılımcı, şeffaf, adil belediye hizmeti sunarak İlimizi turizm, tarım, sanayi ve lojistik sektöründe cazibe merkezi haline getirmek" olarak ifade edilmiştir.

Mersin'den sonra Sağlıklı Kentler Birliği'nde iddialı bir belediye olan İzmir Büyükşehir Belediyesi gelmektedir. İzmir Büyükşehir Belediyesi misyonu "Tarihi ve kültürel değerleri koruyarak, yaşanabilir bir çevre, hızlı ve güvenilir bir ulaşım, planlı bir yerleşim, sistemli alt yapı, duyarlı kentsel dönüşüm hareketi ile kentlilik bilinci oluşturmuş, bilgi ve teknolojiyi etkin yöneten, katılımcl, şeffaf ve her işin merkezine 'insanı' koyan yönetim anlayışından hareket ederek, çağdaş belediyecilik hizmeti sunmak." olarak belirlenmiştir. İzmir gibi misyonunda sağlıklı kent ifadelerini bulunduran diğer bir büyükşehir belediyesi Denizli'dir. Denizli Büyükşehir Belediyesi'nin misyonu “Önce insan anlayışıyla hizmette adalet ve eşitliği ilke edinerek tarihi ve çevresel değerlerine sahip çıan, sağlık ve refah içinde yaşanabilir bir kent oluşturmak" olarak ifade edilmiştir.

Misyonlarında sağlıklı kent ifadelerinin en az bulunduğu büyükşehir belediyeleri ise, Antalya, Aydın, Diyarbakır, Eskişehir, İstanbul, Manisa ve Muğla Büyükşehir Belediyeleridir. Bu belediyelerim misyon ifadeleri şu şekildedir:

Antalya Büyükşehir Belediyesi misyonu; "Antalya halkının ve ziyaretçilerinin yaşamını kolaylaştıran ve değerli kılan en kaliteli yerel 
hizmeti vererek; huzurlu, güvenli, gelişmiş, estetik bir şehirde yaşama imkânı sunma" dır.

Diyarbakır Büyükşehir Belediyesi misyonu; "kentimizde yaşayanların refah ve mutluluğunu artıracak belediyecilik hizmetlerini, ekonomik, etkili ve verimli bir şekilde sunmak" tır.

Eskişehir Büyükşehir Belediyesi misyonu; "Eskişehir'de yaşayan nesillerin daha iyi yetişmesini ve hemşerilerimizin yaşam kalitesini artırarak geleceğe umutla bakmalarını sağlamak" tır. Bu ifade sürdürülebilir kalkınma gibi anlaşılabilir ancak tam olarak onu karşıladı̆̆ı söylenemez.

İstanbul Büyükşehir Belediyesi "Açığa çıkmamış ihtiyaçları karşılayacak hizmetleri, 21. Yüzyılın yerel yönetim anlayışına uygun şekilde sunmak, belediye hizmetlerini kurumsal bir anlayışla mükemmelleştirirken şehrin kültürel kimliğini yaşatmak" tır.

Manisa Büyükşehir Belediyesi misyonunda öncelikle şu ifadeler yer almıştır; "belediyeler, belde halkının ortak ihtiyaçlarını karşılamak üzere kurulmuş kamu kurumlarıdır. Temel misyonu halkın ortak ihtiyaçlarına yönelik hizmet sunma olan belediyelerimizin bu misyonlarını etkin, verimli ve kaliteli biçimde gerçekleştirebilmeleri ve hizmet sundukları kentin yaşam kalitesini geliştirebilmesi için günümüz gelişmiş ülkelerinde uygulama alanı bulan çağdaş belediyecilik anlayışına sahip olmaları gerekmektedir. Bu sebeple, belediyemiz misyonunu "Çağdaş belediyecilik anlayışı çerçevesinde halka hizmet" olarak belirlemiştir."

Muğla Büyükşehir Belediyesi misyonu; "Halkımızın verdiği görev, yetki ve sorumluluklarl; etkinlik, verimlilik, hesap verebilirlik ve şeffaflık ilkeleri doğrultusunda çağdaş yönetim anlayışıyla yerine getirerek Muğla' miza hizmet etmektir"

Görüldüğü üzere sağlıklı kent ifadelerinin en az yer aldığı büyükşehir belediyelerinin misyon ifadelerinde etkinlik ve verimlilik kavramları üzerine yoğunlaşmıştır. Eksik görülen kısım bu hizmetlerin sunulurken hangi değerleri dikkate alınması gerektiği belirtilmemesidir.

\section{Vizyon İfadelerinde Sağlıklı Kent}

Büyükşehir belediyelerinin vizyonları incelenirken sağlıklı kent için belirlenmiş olan ifadelerin birçoğunun yer almadığı görülmüştür. Vizyon 
ifadelerinin daha kısa ve ulaşılması güç olan ifadeler içerdiği ve bazı büyükşehir belediyelerinde bunun hayali olduğu göze çarpmaktadır.

İfadeler kodlanırken doğal güzellikleri korumak; daha yeşil, temiz, güzel; doğayı koruyan; doğal güzelliklere sahip çıkan; Gökyüzünün altındaki en güzel yeryüzünü, tüm yaşam haklarını koruyarak ve güzelliklerini bozmayan; kişi başına düşen yeşil alanda öncü ifadeleri çevre ifadesi ile kodlanmıştır. Yaşanabilir ifadesi anlamına gelen yaşam kalitesi; refah seviyesi yüksek; mutlu ve umutlu insanların yaşadığı; sosyal, kültürel ve ekonomik yönden gelişimini tamamlamış; insanların yaşamaktan zevk alacağı; Planlı gelişim, Estetik Dönüşüm, Fonksiyonel Değişim; Rahat ve konforlu ulaşım sistemlerine sahip, afetlere karşı hazırlıklı, kültürel zenginliğinden güç alan, engellileri ve muhtaçları toplum ile bütünleşmiş; Herkesin görmek ve yaşamak istediği bir Dünya kenti olmak; yaptığı projeler, çalışmalar ve hizmet kalitesiyle dünya çapında örnek ve referans alınan belediye olmak; Kadim şehrimizde, halkımızın refah ve huzur içinde yaşamasını sağlamak ifadeleri yaşanabilir ifadesi ile kodlanmıştır. Konya'mızın ilçeleri arasındaki gelişmişlik farkını en aza indirmek ifadesi ise eşitlik ifadesi ile kodlanmıştır. Uygarlıkların mirasını yaşatan ifadesi hem tarih hem de kültür ifadesi ile kodlanmıştır. Sürdürülebilirlik ifadesi ile aynı anlama gelen gelecek nesillere devretmekten gurur duyulacak; Doğal, tarihi, ekonomik zenginliklerimizi Muğlalılarımıza, yerli ve yabancı konuklarımıza çağdaş bir yönetim anlayışı ile sunmak ve geleceğe taşımak; kenti emanet olarak görmek ifadeleri sürdürülebilir ifadesi ile kodlanmıştır. Plan ifadesi ile aynı anlama gelen kentsel dönüşüm projeleriyle düzenli, disipline edilmiş; "kentleşmesini tamamlamış"; "şehri imar ederken gönülleri fetheden belediye" ifadeleri plan ifadesi ile kodlanmıştır. Kentli ile geleceğin İzmir'ini kuran ifadesi katılım ifadesi ile kodlanmıştır. Kodlama işlemi sonrası oluşan kod-matris tarayıcı tablosu aşağıdadır.

Tablo 2'ye göre adalet ve hesap verilebilirlik ifadeleri hiçbir büyükşehir belediyesinin vizyonunda bulunmamaktadır. Eşitlik ifadesi ise sadece Konya Büyükşehir Belediyesi vizyonunda eşitlik anlamına gelen "Konya'mızın ilçeleri arasındaki gelişmişlik farkını en aza indirmek" ifadesi ile yer almıştır. Burada Konya Büyükşehir Belediyesi ilçe belediyeleri arasındaki gelişmişlik farkını ortadan kaldırarak eşit hizmet sunumu sağlamaya çalışmaktadır. Vizyon ifadelerinde en fazla yer bulan 
ifade yaşanabilir ifadesidir. Bu ifadeden sonra yer bulan ifade $12 \mathrm{kez}$ kullanılan sürdürülebilirlik ve 10 kez kullanılan çevre ifadesidir. Sağlıklı kentler açısından önemli görülen sağlık ifadesi ise vizyonlarda 4 kez yer bulmuştur.

Tablo 2. Vizyon İfadeleri Için Kod-Matris Tarayıcısı

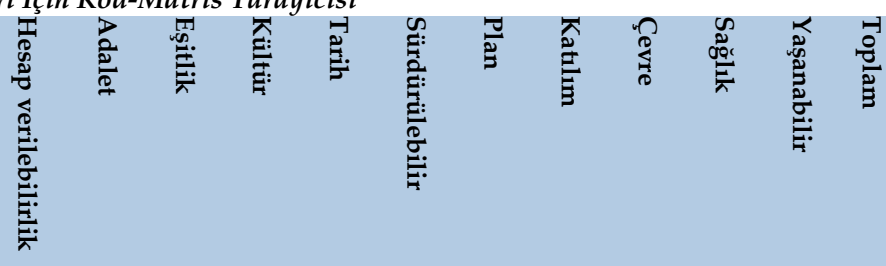

\begin{tabular}{|c|c|c|c|c|c|c|c|c|c|c|c|c|}
\hline Adana & 0 & 0 & 0 & 0 & 0 & 1 & 0 & 0 & 0 & 0 & 0 & 1 \\
\hline Ankara & 0 & 0 & 0 & 0 & 0 & 1 & 0 & 0 & 1 & 1 & 0 & 3 \\
\hline Antalya & 0 & 0 & 0 & 0 & 0 & 0 & 0 & 0 & 0 & 0 & 1 & 1 \\
\hline Aydin & 0 & 0 & 0 & 0 & 0 & 0 & 0 & 1 & 1 & 0 & 0 & 2 \\
\hline Balıkesir & 0 & 0 & 0 & 0 & 1 & 0 & 0 & 0 & 1 & 0 & 1 & 3 \\
\hline Bursa & 0 & 0 & 0 & 0 & 1 & 0 & 1 & 0 & 1 & 1 & 1 & 5 \\
\hline Denizli & 0 & 0 & 0 & 0 & 0 & 0 & 0 & 0 & 1 & 0 & 0 & 1 \\
\hline Diyarbakır & 0 & 0 & 0 & 0 & 0 & 0 & 0 & 0 & 0 & 0 & 1 & 1 \\
\hline Erzurum & 0 & 0 & 0 & 1 & 1 & 0 & 0 & 0 & 0 & 0 & 1 & 3 \\
\hline Eskişehir & 0 & 0 & 0 & 0 & 0 & 1 & 0 & 0 & 0 & 0 & 0 & 1 \\
\hline Gaziantep & 0 & 0 & 0 & 1 & 1 & 1 & 0 & 0 & 0 & 0 & 1 & 4 \\
\hline Hatay & 0 & 0 & 0 & 0 & 0 & 1 & 0 & 0 & 0 & 0 & 1 & 2 \\
\hline İstanbul & 0 & 0 & 0 & 0 & 0 & 1 & 0 & 0 & 0 & 0 & 0 & 1 \\
\hline İzmir & 0 & 0 & 0 & 2 & 1 & 0 & 0 & 1 & 1 & 0 & 0 & 5 \\
\hline Kahramanmaraş & 0 & 0 & 0 & 0 & 0 & 1 & 1 & 0 & 0 & 0 & 1 & 3 \\
\hline Kayseri & 0 & 0 & 0 & 0 & 0 & 0 & 2 & 0 & 0 & 0 & 0 & 2 \\
\hline Kocaeli & 0 & 0 & 0 & 0 & 0 & 1 & 0 & 0 & 0 & 0 & 1 & 2 \\
\hline Konya & 0 & 0 & 1 & 1 & 1 & 0 & 0 & 0 & 0 & 0 & 1 & 4 \\
\hline Malatya & 0 & 0 & 0 & 0 & 0 & 0 & 0 & 0 & 0 & 0 & 1 & 1 \\
\hline Manisa & 0 & 0 & 0 & 0 & 0 & 1 & 0 & 3 & 0 & 2 & 0 & 6 \\
\hline Mardin & 0 & 0 & 0 & 0 & 0 & 0 & 0 & 0 & 0 & 0 & 0 & 0 \\
\hline Mersin & 0 & 0 & 0 & 1 & 0 & 0 & 0 & 0 & 0 & 0 & 1 & 2 \\
\hline Muğla & 0 & 0 & 0 & 0 & 1 & 1 & 0 & 0 & 0 & 0 & 0 & 2 \\
\hline Ordu & 0 & 0 & 0 & 1 & 1 & 1 & 0 & 0 & 1 & 0 & 1 & 5 \\
\hline Sakarya & 0 & 0 & 0 & 1 & 0 & 0 & 0 & 0 & 1 & 0 & 1 & 3 \\
\hline Samsun & 0 & 0 & 0 & 0 & 0 & 0 & 0 & 0 & 0 & 0 & 1 & 1 \\
\hline Şanlıurfa & 0 & 0 & 0 & 0 & 1 & 1 & 1 & 0 & 1 & 0 & 0 & 4 \\
\hline Tekirdağ & 0 & 0 & 0 & 0 & 0 & 0 & 1 & 0 & 1 & 0 & 0 & 2 \\
\hline Trabzon & 0 & 0 & 0 & 0 & 0 & 0 & 1 & 0 & 0 & 0 & 0 & 1 \\
\hline Van & 0 & 0 & 0 & 0 & 0 & 0 & 2 & 0 & 0 & 0 & 1 & 3 \\
\hline TOPLAM & 0 & 0 & 1 & 8 & 9 & 12 & 9 & 5 & 10 & 4 & 16 & 74 \\
\hline
\end{tabular}


Sağlıklı kent ifadelerinin en fazla bulunduğu kentler Manisa, Bursa ve Ordu'dur. Manisa Büyükşehir Belediyesi'nin vizyonunu açıklarken uzun bir açıklama yapmıştır. Belediyenin vizyon ifadesi şu şekildedir; "Şeffaf, katılımcı, Değişen ve gelişen belediye". Bu kapsamda Manisa Büyükşehir Belediyesi'nin vizyonu sağlıklı kent ifadesinin en fazla yer aldığ büyükşehir değildir. Bursa Büyükşehir Belediyesinin vizyonu; "Bursamızı; planlı, sağlıklı, çevreye duyarlı, refah seviyesi yüksek, tarihi değerleri korunan ve tüm kent dinamikleriyle gelişen, sanayi, ticaret ve turizmde lider kent yapmak" dır. Ordu Büyükşehir Belediyesi vizyonu ise "Şehrin coğrafi yapısına, tarihi, kültürel ve doğal değerlerine sahip çıan, kenti emanet olarak görüp sürekli yaşanabilir kılmak için hizmetler üreten, vatandaş odaklı, kurumsallaşmış bir belediye olmak" dır. Adana, Antalya, Denizli, Diyarbakır, Eskişehir, İstanbul, Kayseri, Malatya ve Trabzon Büyükşehir Belediyelerinde sağlıklı kentlere ilişkin tek ifade yer almıştır.

\section{Sonuç}

Kentleşmenin ortaya çıkardığ 1 sorunların çözümünde sağlıklı kent bir çözüm olabilir. Nitekim sağlıklı kent kavramı ve sağlıklı kent ilke ve değerleri kentleşme ve kentleşmenin ortaya çıkardığı çevre ve sağlık sorunlarının çözümünde önemli bir aşamadır. Sağlıklı kent olabilmenin ilkeleri incelendiğinde bu ilkelerin öncelikle çevre sorunlarının çözümüne yönelik olduğu göze çarpmaktadır. Diğer bir sorun olan sağlık sorunları kent nüfusundaki hızlı artış ile özellikle gecekondu bölgelerinde başlayarak tüm kenti etkiler hale gelmiştir. Sağlıklı kente ilişkin bir diğer değer kentsel hayat ve kentsel karar alma süreçlerine katılım ile ilgilidir. Nüfus artışı ile doğrudan demokrasinin uygulanması mümkün değildir. Doğrudan demokrasi yerine uzun yıllardır kullanılan temsili demokrasinin de krize girmesi ve halk katılımına imkân vermemesinden dolayı katılım için yeni yol ve yöntemlere ihtiyaç duyulmaktadır. Sağlıklı kent için temel kriterlerden birisi halkın katılabileceği yeni yol ve yöntemlerin kullanılabileceği katılımcı demokrasi modellerinden birisinin benimsenmesidir. Bu kapsamda kadınlar, çocuklar, yaşlılar, engelliler ve yoksullar gibi dezavantajlı olan grupların karar alma sürecine katılımı ve sorunlarına çözüm odaklı yaklaşmak imkânı sağlanmış olur. Bununla 
birlikte sivil toplum, özel sektör ve kamunun birlikteliği de sağlanmış olur. Sağlıklı kent açısından diğer bir değer ise kentin planlı ve sürdürülebilir olmasıdır. Sürdürülebilir kalkınma kavramı sadece çevre kavramını dikkate alan bir kavram değildir. Sürdürülebilir kalkınmanın diğer iki saç ayağı toplum ve ekonomidir. Bu değerlerin sağlıklı kentte bulunması gerekmektedir. Sürdürülebilir kalkınma ve çevre kavramları ile doğrudan ilgili olan tarihi ve kültürel mirasa sahip çıkılması sağlıklı kentlerde beklenen bir diğer değerdir. Diğer kavram ve ifadeler ile bütünleşen ve insan olmanın değeri açısından önemli olan eşitlik ve adalet kavramlarının yeri ve önemi ayrıdır. Yönetişim ilkelerinden biri olan hesap verilebilirlik kavramı sağlıklı kentin özellikle katılım kavramı ile bütünleşen ve bireylerin katılımını kolaylaştıran bir kavramdır. Sağlıklı kent kentte yaşayanlar için yaşanabilir bir kent oluşturması gerekmektedir. Yaşanabilir bir kentte tüm sağlıklı kent değerlerinin yer alması gerekmektedir.

Büyükşehir belediyeleri hem kentsel alan hem de kırsal alanı barından önemli idari birimler olduklarından ve sağlıklı kentler projesinin doğrudan paydaşı olmasından dolayı bu çalışmanın alanını oluşturmaktadır. Çalışma incelenirken stratejik planlarda yer alan vizyon ve misyon kavramlarının sağlıklı kenti hangi oranda karşıladığı bulunmaya çalışılmıştır. Misyon ifadeleri belediyelerin görevleri ve yakın geleceğe ilişkin örgütsel amaçları belirtmesi gerekmektedir. Vizyon ifadesi ise uzak geleceği ilişkin ulaşılabilir hedefler içermesi gerekmektedir. Ancak büyükşehir belediyelerinin vizyon ve misyonları bu kavramsal tanımlamayı tam olarak karşılamamaktadır. Bu kapsamda büyükşehir belediyelerinin misyon ve vizyonlarının tekrar gözden geçirilmesi gerekmektedir. Bu değişiklikler yapılırken öncelikle kentin kent halkı açısından yaşanabilir, çevreye duyarlı, planlı, katılımcı, eşitlik ve adalet ilkelerine uygun, tarihi ve kültürel mirasa sahip çıkan sürdürülebilir sağlıklı bir kent olmasını sağlayacak ifadelere yer verilmelidir. Böylece stratejik planı oluşturan tema ve amaçlarda buna uygun gerçekleşecektir. Misyon ve vizyon sadece stratejik plan açısından değil aynı zamanda vatandaşa hizmet sunarken ve personelin birbiri ile ilişkileri ve görev alanlarının belirlenmesi ve kurumsal aidiyet duygusunun gelişmesi açısından kullanılabilecek önemli kavramlardır. 
Sağlıklı kent açısından incelediğimiz 29 büyükşehrin (Mardin Büyükşehir Belediyesi'nin vizyon ve misyonuna ulaşılamamıştır.) hiçbiri tam olarak sağlıklı kente ilişkin değerleri misyon ve vizyonlarına taşıyamamıştır. Ancak Türkiye Sağlıklı Kentler Birliği Üyesi olan belediyelerin bu değerlere diğer belediyelerden daha fazla önem verdiği göze çarpmaktadır. Ancak bununda istisnası bulunmaktadır. Örneğin İstanbul Büyükşehir Belediyesi Türkiye Sağlıklı Kentler Birliği üyesi olmasına rağmen vizyon ve misyon ifadelerinde bunu karşılayamamıştır. Bursa, İzmir, Denizli ve kısmen de Kahramanmaraş Büyükşehir Belediyesi sağlıklı kent ifadelerini misyon ve vizyonunda yer vermiştir. Trabzon ve Tekirdağ Büyükşehir Belediyeleri misyonlarında sağlıklı kent ifadelerine yer verirken vizyonlarında bu konuda biraz daha geride kalmışlardır. Mersin Büyükşehir Belediyesi misyonunda sağlıklı kente ilişkin ifadelere en fazla yer veren belediye iken vizyonda bu konuda çok geride kalmıştır. Şanlıurfa Büyükşehir Belediyesi Türkiye Sağlıklı Kentler Birliği'ne üye değildir ancak misyon ve vizyonunda orta seviyede sağlıklı kent ifadelerine yer vermiştir. Konya Büyükşehir Belediyesi de Şanlıurfa Büyükşehir Belediyesi gibi Birlik üyesi olmamakla birlikte vizyon ve misyonunda bu ifadelere yer vermiştir.

Sonuç olarak tüm büyükşehir belediyelerinin sağlıklı kentler birliğine üye olması kentleşmenin ortaya çıkardığı çevre ve sağlık sorunlarının çözümünde önemli bir aşama için başlangıç olacağı aşikardır. Ancak üye olmak yeterli değildir. Belediyelerin sağlıklı kentti içselleştirmeleri gerekmektedir. Bunun yolu da tüm eylem ve işlemleri için yol gösterici ve rehber olan misyon ve vizyonlarında bu ifadeye yer verecek sağliklı misyon ve vizyonlar oluşturmalarıdır. Baştan savma ve resmi bir işlemi halletmek için oluşturulacak misyon ve vizyonlar belediyelerin geleceğine 1şık tutamayacağı gibi yeni sorunların ortaya çıkmasına da sebep olacaktır. 


\section{EXTENDED ABSTRACT}

\section{A Comparative Analysis of the Metropolitan Municipality and Healthy Cities in Turkey}

\section{Aziz Belli}

\section{Kahramanmaraş Sütçü İmama University}

Healthy city can be a solution to the problems of urbanization. Indeed, the concept of healthy cities and healthy urban principles and its values are an important stage in the solution of the environment and health problems caused by urbanization. When the principles of being a healthy city are examined, it is shown that these principles are primarily aimed at solving environmental problems. Health problems as an another issue, especially with the rapid increase in the urban population, affect the entire city starting from the slums. Another principle in the healthy city is related to urban life and participation in urban decision-making processes. With population growth, it is not possible to implement direct democracy. Instead of direct democracy, the representative democracy has been used for many years. But it does not allow for public participation. So, the new ways and methods are needed for participation. One of the main criteria for a healthy city is the adoption of one of the participatory democracy models in which new ways and methods can be used by the public. Within this scope, participation of disadvantaged groups such as women, children, elderly people, disabled and poor people in decision-making process and solution-oriented approach to their problems are provided. In addition, civil society, private sector and public unity are also provided. Another value in terms of healthy city is that the city is planned and sustainable. The concept of sustainable development does not only consider the concept of environment. There are two other pillars of sustainable development; society and economy. These values should be in in healty city. The historical and cultural heritage that is directly related to the concepts of sustainable development and environment is another value expected in healthy cities. The place and importance of the concepts of equality and justice, which are integrated 
with other concepts and expressions and which are important in terms of the value of being human, are seperated. The concept of accountability, which is one of the principles of governance, is a concept that integrates with the concept of participation of the healthy city and facilitates the participation of individuals. The healthy city should create a livable city for the inhabitants of the city. In a livable city, all healthy urban values should be included.

Metropolitan municipalities form the field of study. Because they are important administrative units in both urban and rural areas. They are also direct stakeholders of the healthy cities project. While examining this study, it was tried to find out the ratio of vision and mission concepts in strategic plans to meet the healthy city. The definitions of the mission should specify the tasks of the municipalities and their organizational objectives for the near future. The definition of vision should include achievable targets for the distant future. However, the vision and missions of metropolitan municipalities do not fully meet this conceptual definition. In this context, the mission and vision of metropolitan municipalities need to be reviewed again. While making these changes, first of all, these expressions shall be included; inhabitable city for the people, ecofriendly, planned, supports participatory, compatible with the principles of equality and justice and to protect historical and cultural heritage. Thus, the theme and objectives of the strategic plan will be realized accordingly. Mission and vision are not just an important concept for the strategic plan. Also, these are important concepts that can be used dor providing services to citizens and to identify the relations of personnel with each other and the areas of duty and to develop the sense of corporate belonging.

The missions and visions of the 29 metropolitan cities (Mardin Metropolitan Municipality's vision and mission could not be included) have not been able to carry the values of the healthy city. However, the municipalities, which are the members of Turkey Healthy Cities Association, stands out from other municipalities that give more importance to these values. However, there are some exceptions; For example, despite being a member of the Turkey Healthy Cities Association, Istanbul Metropoli$\tan$ Municipality, didn't mention the expressions in their vision and mission. Bursa, İzmir, Denizli and partly Kahramanmaraş Metropolitan 
Municipalities have included healthy city expressions in their missions and visions. Trabzon and Tekirdag Metropolitan Municipalities focused on healthy cities in their missions but got behind in their visions. Mersin Metropolitan Municipality is the municipality that gives the most place to the statements about the healthy city in its mission, but far behind in their vision. Sanliurfa Metropolitan Municipality is not a member of the Turkish Healthy Cities Association, but in their mission and vision, they have focused on a healthy city expression at moderate level. Konya Metropolitan Municipality, like Şanlıurfa Metropolitan Municipality is not a member of the Association but has included almost same statements in its vision and mission.

As a result, if all metropolitan municipalities will be the member of Turkish Healty Cities Association, will be an important step in the solution of the environmental and health problems caused by urbanization. However, becoming a member won't be enough. Municipalities must internalize the healthy city. The way to do this is to create reliable missions and visions that will include this statement in their mission and visions as a guide for all their actions and operations. If the missions and visions created to take over as a sloppy and to do a formal process, can not offer an insight into future of the municipalities and it also leads to new problems.

\section{Kaynakça / References}

29 Büyükşehir Belediyesi Stratejik Planı (Mardin Büyükşehir Belediyesi Hariç).

5216 sayılı Büyükşehir Belediyesi Kanunu.

6360 sayılı On Üç İlde Büyükşehir Belediyesi ve Yirmi Yedi İlçe Kurulması İle Bazı Kanun ve Kanun Hükmünde Kararnamelerde Değişiklik Yapılmasına Dair Kanun.

Altuntaş, A. (2012). Sürdürülebilir toplumlar ve metropollerin baskılarından kurtulmak için alternatif bir yol: Sürdürülebilir kentler. Mustafa Kemal Üniversitesi Sosyal Bilimler Enstitüsü Dergisi, 9(17), 135-148.

Aycan, Sefer, "Sağlıklı Kentler", https://seferaycan.wordpress.com/2011/03/21/saglikli-sehirler, E.T:: 23.12.2018. 
Aydın, A. ve Belli A. (2018). Modern çağda müslüman kent: Medine'den metropole. Modernleşme Sürecinde Müslümanlar, (Ed.: Necmettin Çalışkan), Ankara: Nobel Yayınevi.

Başaran, İ. (2007). Sağlıklı kentler kavramının gelişiminde sağlıklı kentler projesi. Dokuz Eylül Üniversitesi Sosyal Bilimler Enstitüsü Dergisi, 9(3), 207-229.

Belli A. ve Aydın A. (2017). 6360 sayılı kanun ve yerelde merkezileşme. International Journal of Social Science, 55, 401-413. Doi:http://dx.doi.org/10.9761/JASSS6945,

Belli, A. ve Aydın, A. (2016). Dünya sağlık örgütü sağlıklı kent projesi kapsaminda Aksaray belediyesinin değerlendirilmesi, I. Uluslararası Aksaray Sempozyumu, 27-29 Ekim 2016, Aksaray.

Bulut, Y. (2005). GAP bölgesinde kentleşme. Ankara: Nobel Yayınevi.

Çetin, S. (2009). Vizyon yönetimi. Selçuk Üniversitesi Sosyal Bilimler Enstitüsü Dergisi, 22, 96-103.

Edwards, P. ve Tsourus, A.D., (2008). A healthy city is an active city: a physical activity planning guide. WHO Regional Office for Europe.

Erkan, R. (2010). Kentleşme ve sosyal değişme. Ankara: Bilimadamı Yayınları.

Glaeser, E.L., (2013). A world of cities: The causes and consequences of urbanization in poorer countries. National Bureau Of Economic Research, UK.

İnce, R.A. (2015). Türkiye'nin ikinci 500 büyük şirketinin misyon ve vizyon ifadelerine göre girişimcilik özellikleri. Ni⿱̆gde Üniversitesi İktisadi ve İdari Bilimler Fakültesi Dergisi, 8(2), 143-155.

İzmir

Büyükşehir

Belediyesi, http://skpo.izmir.bel.tr/Bagimsiz.aspx?MID=6, E.T.: 20.12.2018.

Jaysawal N. ve Saha S. (2014). Urbanization in India: An impact assessment. International Journal of Applied Sociology 4(2), 60-65 DOI: 10.5923/j.ijas.20140402.04.

Leeuw, E., (2001). Global and local (glocal) health: The who healthy cities programme. Global Change \& Human Health, 2(1), 34-45.

McGranahan , G. ve Satterthwaite, D. (2014). Urbanisation concepts and trends, IIED, http://pubs.iied.org/pdfs/10709IIED.pdf, E.T.: 20.12.2019. 
Muslu, Ş. (2014). Örgütlerde misyon ve vizyon kavramlarının önemi. HAK-IŞ Uluslararası Emek ve Toplum Dergisi, 3(5), 150-171.

Ocak, M., Güler M. ve Basım, N.H. (2016). Türk savunma sanayi firmalar1 vizyon ve misyon ifadelerinin içerik analizi. Yönetim ve Ekonomi, 23(2), 205-518.

Ok, V. (2007). Sağlıklı kentler için pasif iklimlendirme ve bina aerodinamiği. VIII. Ulusal Tesisat Mühendisliği Kongresi Bildiri Kitabı, ss. 213-227.

Okçu, M. ve Kaya, E. (2008). Sağlıklı şehirler oluşturma sürecinde yerel yönetimlerin rolü. 1. Ulusal Yerel Yönetimler Sempozyumu Bildiri Kitabl, ss. 363-376.

Özcan, A. (2007). Ekolojik temele dayalı sürdürülebilir kentsel gelişme: Malatya kent örneği üzerinden bir değerlendirme. 38. ICANAS Uluslararası Asya ve Kuzey Afrika Çalışmaları Kongresi, 2(1), .685707.

Papulova, Z. (2014). The significance of vision and mission development for enterprises in Slovak Republic. Journal of Economics, Business and Management, 2(1), 12-16.

Pawan, (2016). Urbanization and Its Causes and Effects: A Review. International Journal of Research and Scientific Innovation (IJRSI), III/IX, ss. $110-112$.

Peng, X.,Chen, X., and Cheng,Y. (2000). Urbanization and its consequences. Demography Vol. II. http://www.eolss.net/EolssSampleallchapter.aspx. E.T.: 15.12.2018.

Sharma B ve Nam E.W. (2017). A healthy city project: A case study of wonju city, South Korea and its relevance to the cities in Nepal. Journal of Gandaki Medical College-Nepal, 10(1), 34-42.

Susmaz, E. ve Ekinci E.C., (2009). Sağlıklı kentleşme süreci esasları. EJournal of New World Sciences Academy, 481), 21-34.

Şahin, Y., (2018). Kentleşme politikası. Bursa:Ekin Yayınevi.

Şarköy Vizyon Planı, (2011), Trakya Kalkınma Ajansı.

T.C. 1982 Anayasası.

T.C. Sağlık Bakanlığı, Temel Sağlık Hizmetleri Genel Müdürlüğü, Türkiye'de bulaşıcı olmayan hastalıklar ve risk faktörleri ile mücadele politikaları, Ankara, Yayın No: 809, http://www.saglikaktuel.com/d/file/ulke_raporu_baski_hali_tr.pdf, E.T.: 20.12.2018. 
Tanković A.C. (2013). Defining strategy using vision and mission statements of croatian organizations in times of crisis. Ekonomska istraživanja - Economic Research, Special Issue, 331-342.

Tosun Karakurt, E. (2009). Sürdürülebilirlik olgusu ve kentsel yapıya etkileri. Paradoks, Ekonomi, Sosyoloji ve Politika Dergisi, 5(1),103120.

Tsourus, A.D. (2017). City leadership for health and sustainable development. Ministry of Health, Kuwait.

Türk Dil Kurumu, www.tdk.gov.tr, E.T.: 02.01.2019.

Türkiye Sağlıklı Kentler Birliği Tüzüğü,

Türkiye Sağlıklı Kentler Birliği, http://www.skb.org.tr/birlikhakkinda/birlik-hakkinda, E.T.: 20.12.2018.

WHO, https://www.who.int/healthpromotion/conferences/previous/jakarta/declaration/en/index1.html, E.T.: 28.12.2018.

WHO, https:/www.who.int/healthy_settings/types/cities/en/, E.T.: 21.12.2018

World Health Organization Regional Office For Europe, (1997). Twenty steps for developing a healthy cities project.

Yalova Valiliği Çevre ve Şehircilik İl Müdürlüğü, http://yalova.csb.gov.tr/saglikli-kent-nedir-kriterleri-nelerdirhaber-169094, E.T.: 25.12.2018.

Yıldırım, A. ve Şimşek, H., (2004). Sosyal bilimlerde nitel araştırma yöntemleri. Ankara: Seçkin Yayıncılık.

\section{Kaynakça Bilgisi / Citation Information}

Belli, A. (2019). Türkiye'de sağlıklı kentler ve büyükşehir belediyeleri üzerine karşılaştırmalı bir analiz. OPUS-Uluslararası Toplum Araştırmaları Dergisi, 10(17), 1930-1962. DOI:10.26466/opus .512721 